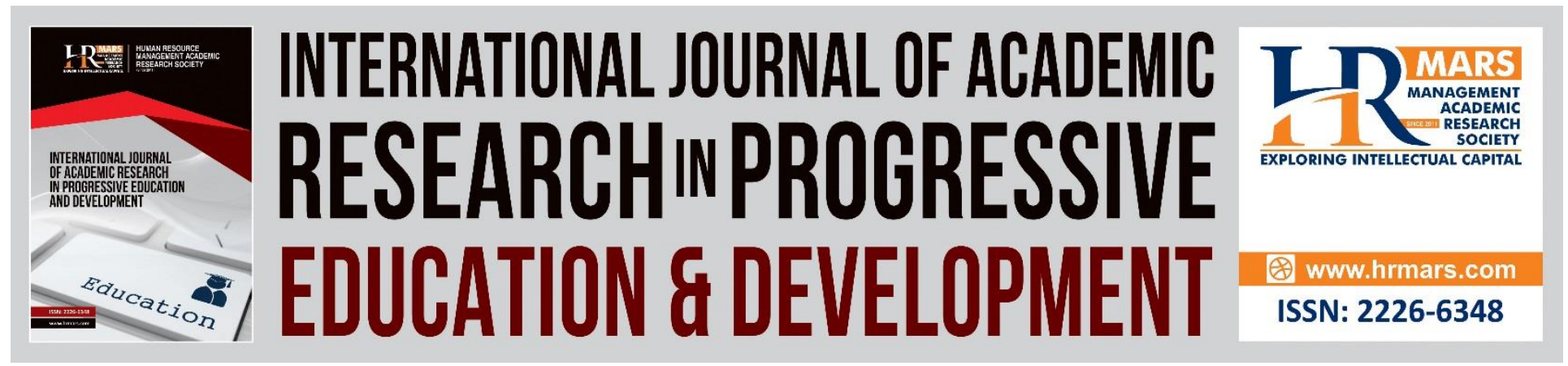

\title{
Impact of Education Management Information System (EMIS) on Teaching-Learning Development
}

\author{
Md. Shafiqul Alam Helal, Ikbal Ahmed, Md. Eunus Mia Bhuiyan
}

To Link this Article: http://dx.doi.org/10.6007/IJARPED/v10-i2/10443 DOI:10.6007/IJARPED/v10-i2/10443

Received: 06 April 2021, Revised: 10 May 2021, Accepted: 10 June 2021

Published Online: 24 June 2021

In-Text Citation: (Helal et al., 2021)

To Cite this Article: Helal, M. S. A., Ahmed, I., \& Bhuiyan, M. E. M. (2021). Impact of Education Management Information System (EMIS) on Teaching-Learning Development. International Journal of Academic Research in Progressive Education and Development, 10(2), 948-956.

Copyright: (C) 2021 The Author(s)

Published by Human Resource Management Academic Research Society (www.hrmars.com)

This article is published under the Creative Commons Attribution (CC BY 4.0) license. Anyone may reproduce, distribute, translate and create derivative works of this article (for both commercial and non-commercial purposes), subject to full attribution to the original publication and authors. The full terms of this license may be seen at: http://creativecommons.org/licences/by/4.0/legalcode

Vol. 10(2) 2021, Pg. 948 - 956

http://hrmars.com/index.php/pages/detail/IJARPED

JOURNAL HOMEPAGE

Full Terms \& Conditions of access and use can be found at http://hrmars.com/index.php/pages/detail/publication-ethics 


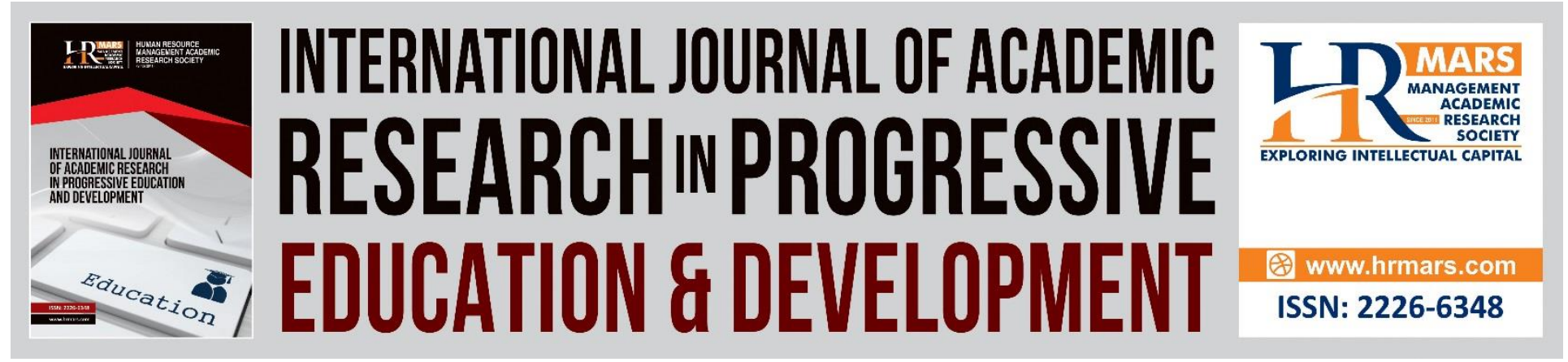

\title{
Impact of Education Management Information System (EMIS) on Teaching-Learning Development
}

\author{
Md. Shafiqul Alam Helal ${ }^{1}$, Ikbal Ahmed², Md. Eunus Mia Bhuiyan ${ }^{3}$ \\ ${ }^{1}$ Principal, Ibn Taimiya School \& College, ${ }^{2}$ Lecturer, Dept of CSE, CCN University of Science \& \\ Technology, ${ }^{3}$ Lecturer, Dept. of English, CCN University of Science \& Technology
}

\begin{abstract}
In today's world, EMIS has become a critical component. It was created with the intent of monitoring the institute's educational program performance and managing the distribution and allocation of educational resources. Of course, in education, EMIS plays a particular function in assisting a school's growth. It is concerned with a system for managing a vast amount of data and information that can be quickly accessed, processed, analyzed, and disseminated. The sample was chosen at random using an automated sample calculator that indicated a minimum of $\mathbf{3 7 9}$ people. In the school administration, the questionnaire was sent electronically through email, Facebook, and WhatsApp. The total number of answers received was 115 , representing a $40 \%$ return rate. To address the study questions, the researchers used descriptive statistical analysis. The researchers were able to conclude from the data analysis procedures that schools successfully utilize EMIS in terms of reported ease of use and perceived utility, as shown by the mean ratings. It was discovered that EMIS has a substantial effect on teaching and learning growth.

Keywords: EMIS, Student Performance, Teacher Performance, Administrative Performance, Teaching-Learning

\section{Introduction}

EMIS stands for education management information system, and it is a system for managing educational data. This system is known by a variety of names in various situations. According to EMIS, an EMIS can handle a wide range of data, including demographics, enrollment, discipline, and other functional elements for students; learning data such as assessment and achievement data, teacher evaluations, curriculum effectiveness data, and other factors related to progression through educational institutions. Assessing the status of education in a nation requires knowledge about the educational system's inputs, resources, governance, operations, and results. An education management information system (EMIS) offers systematic, high-quality data in a well-structured enabling environment that makes it easier to use the data in planning and policy discussions. The primary goal of this article is to sketch out the EMIS Tool's structure.
\end{abstract}


The article begins by outlining current data-related needs for enhancing education, as well as how an EMIS works to fulfill those expectations. It then goes through what's presently in EMIS systems by going over EMIS activities and emphasizing EMIS experiences that the benchmarking tool will use.

\section{Functions of EMIS}

EMIS facilitates decision-making in both structural and unistructural issue situations, as well as at all levels of the organization. It is meant to be weaved into the organization's fabric rather than standing alone. People, computers, processes, databases, interactive query tools, and other components make up MIS. It refers to the gathering, storing, and transmitting of information to prospective consumers. They're designed to be evolutionary and adaptable, as well as simple to use. We'd want to learn more about how certain data and systems might help with decisionmaking.

\section{EMIS Activities}

1. Data Collection: The necessary data is gathered and recorded on a form called a source dozed comment that serves as input to the system.

2. Verification: The data is edited in some manner to verify its accuracy.

Sometimes the data entry operator visually verifies the data as it is displayed on the screen. Any errors are corrected at that time.

3. Storage: The data are stored on some medium such as diskette or tape.

4. Security: While the data exist in storage, it is kept secure to prevent destruction, damage, or measure.

5. Organization: the data can be arranged in various sequences to increase its information value.

6. Retrieval: the data is made available to authorized users.

\section{Research Objectives}

1. To find out the importance of EMIS during the sudden closure of institutions.

2. To find out the impact of EMIS on Teaching-Learning development.

3. To find out the impact of teachers' performance on Teaching-Learning development.

4. To find out the impact of students' performance on Teaching-Learning development.

\section{Research Questions}

1. How important is EMIS during the sudden closure of institutions?

2. What is the impact of EMIS on Teaching-Learning development?

3. What is the impact of teachers' performance on Teaching-Learning development?

4. What is the impact of students' performance on Teaching-Learning development?

\section{Literature Review}

The importance of EMIS is found abundantly in many articles on EMIS. Actually, for the betterment of any institution, its importance is beyond description. As stated by OdinahLanderoCuartero and Mylene Role (2018), many public schools update their documents 
honestly and carefully at the end of the school year. Thus, they can evaluate the teachers' performance in school with these updated documents because of persistent changes and progress of learner information system. Jose Martin and co-authors (2019) tried to determine the feasibility of the prevailing linear correlation between the proposed conceptual model variables. They understood that most prevailing relations are relatively strong. They also suggested carrying on further empirical research to have positive results following their model. Their research carries an innovative artifact composed of multiple dimensions and conducted at study if EMIS readily increases tertiary level students' progress or not. Finally, it proves that their progress is ensured. "The structure, cohesiveness, and deployment of the various EMIS affected the resources needed to create and manage them," according to a UNICEF East Asia and Pacific (2020) study on "Review of EMIS that Track Individual Students Data." According to the data, nations interested in pursuing individual Student Tracking would benefit from a defined strategy and implementation plan that takes into account capacity building requirements at all levels of government. Student Tracking systems were also utilized in the nations studied to monitor students in and out of school and manage dropout problems. Student Tracking was shown to offer better statistical data for national education statistics in the nations studied. There is also evidence that Student Tracking systems in government environments with high levels of interoperability between sector information systems, such as those in health, education, and social welfare, can provide a more holistic picture of each child's wellbeing and help determine whether a child is participating in mandated and essential services."

\section{Methodology}

A quantitative research design was employed to conduct this study to measure the adverse impact associated with the use of technological devices on students' performance.

\section{Data Collection}

The data is collected using the convenience sampling technique. The questionnaire survey is carried out through the internet. To achieve a sample size of 115 respondents, questionnaires were sent through a link to respondents via email, Facebook, and WhatsApp.

\section{Questionnaire Design}

The effect of utilizing EMIS for educational objectives is determined using a quantitative method. This indicates that the study is based on a questionnaire survey administered to a sample of the target population. Closed-ended questions were asked of respondents on the questionnaire to evaluate their demographic profile. Their reactions to the use of EMIS are recorded using a fivepoint Likert scale. The Likert scale is based on a five-point scale, with 1 indicating strong disagreement and 5 indicating strong agreement.

\section{Research Hypotheses \\ Null Hypothesis}

$\mathrm{H}_{\mathbf{0}}$ : The usage of EMIS has no impacton Teaching-Learning Development.

$\mathbf{H}_{\mathbf{0}}$ 2: Teacher performance hasno impacton Teaching-Learning Development.

$\mathbf{H}_{0} 3$ : Student performance has no impacton Teaching-Learning Development. 
INTERNATIONAL JOURNAL OF ACADEMIC RESEARCH IN PROGRESSIVE EDUCATION AND DEVELOPMENT

Vol. 10, No. 2, 2021, E-ISSN: 2226-6348 @ 2021 HRMARS

$\mathbf{H}_{0}$ : Administrative performance has noimpacton Teaching-Learning Development.

\section{Alternative Hypothesis}

$\mathbf{H}_{\mathrm{A}} \mathbf{1}$ : The usage of EMIS has an impacton Teaching-Learning Development.

$\mathbf{H}_{\mathrm{A}}$ 2: Teacher performance has an impacton Teaching-Learning Development.

$\mathbf{H}_{\mathrm{A}}$ 3: Student performance has an impacton Teaching-Learning Development.

$\mathbf{H}_{\mathrm{A}}$ 4: Administrative performance has an impacton Teaching-Learning Development.

\section{Data Analysis}

Descriptive Statistics

Table 1: Descriptive Statistics (Teacher Performance)

\begin{tabular}{|l|c|c|c|c|}
\hline Teacher Performance & $\begin{array}{c}\text { Mean } \\
\text { Statistics }\end{array}$ & $\begin{array}{c}\text { Std. Error } \\
\text { of Mean }\end{array}$ & $\begin{array}{c}\text { Std. Deviation } \\
\text { Statistics }\end{array}$ & $\begin{array}{c}\text { Variance } \\
\text { Statistics }\end{array}$ \\
\hline EMIS Creates Teacher's Awareness & 4.21 & 0.063 & 0.680 & 0.463 \\
\hline EMIS fulfills the main purpose & 3.42 & 0.100 & 1.077 & 1.159 \\
\hline $\begin{array}{l}\text { EMIS is specially designed to monitor } \\
\text { the performance of education } \\
\text { programs }\end{array}$ & 3.97 & 0.071 & 0.758 & 0.575 \\
\hline $\begin{array}{l}\text { EMIS domains for better academic } \\
\text { results }\end{array}$ & 4.00 & 0.071 & 0.766 & 0.586 \\
\hline
\end{tabular}

Teacher performance refers to how an instructor instructs students in class and how students respond to the teacher (Al Qalhati et al., 2020). As a result, this issue is critical to the advancement of education and acts as a stepping stone for students' improvement. The mean, standard deviation, and variance of 115 respondents for each item included in the teacher performance are shown in the table above. The findings indicate that the numbers for each item vary from 3.4 to 4.2 , indicating a neutral to agreed reaction for the topic in question. The computed standard deviation and variance numbers also show that teacher performance in the educational system is highly successful, since they show a decreased distance from the mean.

Table 2: Descriptive Statistics (Student Performance)

\begin{tabular}{|l|c|c|c|c|}
\hline Student Performance & $\begin{array}{c}\text { Mean } \\
\text { Statistics }\end{array}$ & $\begin{array}{c}\text { Std. Error } \\
\text { of Mean }\end{array}$ & $\begin{array}{c}\text { Std. Deviation } \\
\text { Statistics }\end{array}$ & $\begin{array}{c}\text { Variance } \\
\text { Statistics }\end{array}$ \\
\hline EMIS fulfills the main purpose & 3.42 & 0.100 & 1.077 & 1.159 \\
\hline $\begin{array}{l}\text { EMIS is important for the case study } \\
\text { of every student }\end{array}$ & 4.05 & 0.067 & 0.729 & 0.532 \\
\hline $\begin{array}{l}\text { EMIS is specially designed to monitor } \\
\text { the performance of education } \\
\text { programs }\end{array}$ & 3.97 & 0.071 & 0.758 & 0.575 \\
\hline $\begin{array}{l}\text { EMIS domains for better academic } \\
\text { results }\end{array}$ & 4.00 & 0.071 & 0.766 & 0.586 \\
\hline
\end{tabular}


Vol. 10, No. 2, 2021, E-ISSN: 2226-6348 @ 2021 HRMARS

The academic achievement of students is determined by their grades. It is mainly determined by the teacher's performance and the organization's management. The table displays the mean value for each item, which ranges from 3.4 to 4.0, indicating participants' acceptance of the Teaching-Learning development's dependence on student achievement. Furthermore, the standard deviation and variance numbers are also low, indicating that using EMIS has a favorable effect on student performance.

Table 3: Descriptive Statistics (Administrative Performance)

\begin{tabular}{|l|c|c|c|c|}
\hline Administrative Performance & $\begin{array}{c}\text { Mean } \\
\text { Statistics }\end{array}$ & $\begin{array}{c}\text { Std. Error } \\
\text { of Mean }\end{array}$ & $\begin{array}{c}\text { Std. Deviation } \\
\text { Statistics }\end{array}$ & $\begin{array}{c}\text { Variance } \\
\text { Statistics }\end{array}$ \\
\hline $\begin{array}{l}\text { Implementation of EMIS is complex } \\
\text { for any institution }\end{array}$ & 3.10 & 0.098 & 1.062 & 1.127 \\
\hline EMIS is expensive for any institution & 2.83 & 0.111 & 1.114 & 1.241 \\
\hline $\begin{array}{l}\text { EMIS is essential for proper decision } \\
\text { making related to education } \\
\text { instantly }\end{array}$ & 4.03 & 0.071 & 0.765 & 0.585 \\
\hline EMIS is necessary for data collection & 4.14 & 0.063 & 0.681 & 0.464 \\
\hline $\begin{array}{l}\text { Educational institutions get a lot of } \\
\text { benefits from EMIS software }\end{array}$ & 4.15 & 0.069 & 0.746 & 0.556 \\
\hline $\begin{array}{l}\text { Increasing the professional of } \\
\text { statisticians is essential }\end{array}$ & 3.99 & 0.075 & 0.815 & 0.664 \\
\hline Data can be leaked out due to EMIS & 3.22 & 0.096 & 1.043 & 1.088 \\
\hline
\end{tabular}

The effectiveness of administrative officers and assistance determines administrative performance. Furthermore, administrative efficiency is hampered by a lack of technical expertise and a lack of secrecy. Table 3 shows that the table's mean value is within the range of $2.83-4.15$, indicating that the sample respondents' answers were neutral for each item.

Table 4: Descriptive Statistics (The usage of EMIS)

\begin{tabular}{|l|c|c|c|c|}
\hline The usage of EMIS & $\begin{array}{c}\text { Mean } \\
\text { Statistics }\end{array}$ & $\begin{array}{c}\text { Std. Error } \\
\text { of Mean }\end{array}$ & $\begin{array}{c}\text { Std. Deviation } \\
\text { Statistics }\end{array}$ & $\begin{array}{c}\text { Variance } \\
\text { Statistics }\end{array}$ \\
\hline $\begin{array}{l}\text { Increasing the professional of } \\
\text { statisticians is essential }\end{array}$ & 3.99 & 0.075 & 0.815 & 0.664 \\
\hline $\begin{array}{l}\text { EMIS is specially designed to monitor } \\
\text { the performance of education } \\
\text { programs }\end{array}$ & 3.97 & 0.071 & 0.758 & 0.575 \\
\hline $\begin{array}{l}\text { Educational institutions get a lot of } \\
\text { benefits from EMIS software }\end{array}$ & 4.15 & 0.069 & 0.746 & 0.556 \\
\hline $\begin{array}{l}\text { EMIS is essential for proper decision } \\
\text { making related to education } \\
\text { instantly }\end{array}$ & 4.03 & 0.071 & 0.765 & 0.585 \\
\hline $\begin{array}{l}\text { Implementation of EMIS is complex } \\
\text { for any institution }\end{array}$ & 3.10 & 0.098 & 1.062 & 1.127 \\
\hline
\end{tabular}


Vol. 10, No. 2, 2021, E-ISSN: 2226-6348 @ 2021 HRMARS

EMIS stands for education management information system, and it is a system for managing educational data. This system is known by a variety of names in various situations. Table 4 shows that the mean value for each item is in the range of 3.1-4.1, indicating that the willingness to use EMIS is essential for teaching-learning growth.

Table 5: Descriptive Statistics (Teaching-Learning Development)

\begin{tabular}{|l|c|c|c|c|}
\hline Teaching-Learning Development & $\begin{array}{c}\text { Mean } \\
\text { Statistics }\end{array}$ & $\begin{array}{c}\text { Std. Error } \\
\text { of Mean }\end{array}$ & $\begin{array}{c}\text { Std. Deviation } \\
\text { Statistics }\end{array}$ & $\begin{array}{c}\text { Variance } \\
\text { Statistics }\end{array}$ \\
\hline $\begin{array}{l}\text { EMIS domains for } \\
\text { better academic results }\end{array}$ & 4.00 & 0.071 & 0.766 & 0.588 \\
\hline $\begin{array}{l}\text { EMIS is specially designed } \\
\text { to monitor the performance } \\
\text { of education programs }\end{array}$ & 3.97 & 0.071 & 0.758 & 0.575 \\
\hline $\begin{array}{l}\text { For every institution } \\
\text { EMIS is very important for } \\
\text { development of education }\end{array}$ & 4.31 & 0.081 & 0.876 & 0.767 \\
\hline $\begin{array}{l}\text { Without EMIS progress } \\
\text { in education will be less } \\
\text { in the period of Covid-19 pandemic }\end{array}$ & 3.72 & 0.075 & 0.808 & 0.653 \\
\hline $\begin{array}{l}\text { EMIS is essential for proper decision } \\
\text { making related to education } \\
\text { instantly }\end{array}$ & 4.03 & 0.071 & 0.765 & 0.585 \\
\hline
\end{tabular}

The effect of student performance, teacher performance, administration performance, and EMIS use on Teaching-Learning Development is represented by this variable. The bigger the effect of their performance, the more likely the Teaching-Learning process will grow. The mean of Teaching-Learning Development, the study's dependent variable, is $3.72-4.03$ for each item in the table above, showing that the majority of respondents believed that student-teacheradministrative performance influences Teaching-Learning development with a low standard deviation.

\section{Inferential Statistics}

A study instrument of 15 questions was utilized to evaluate the effect of the application of EMIS in the context of educational institution management, and an exploratory analysis was performed. Inferential statistics aid in the extraction of conclusions and conclusive evidence from a population's sample data (Gillet, Fouquereau, Forest, Brunault\&Colombat, 2012; Inoue, Kawakami, Tsuno, Tomioka, \& Nakanishi, 2012; Rita Silva \& Caetano, 2014). Many variables are reduced to the most essential ones using exploratory factor analysis using SPSS (Buyukoztur, 2007; Tavsancil, 2002). The remaining elements resulted in a reliable model, which was used for reliability and validity testing, as well as route analysis. 
INTERNATIONAL JOURNAL OF ACADEMIC RESEARCH IN PROGRESSIVE EDUCATION AND

DEVELOPMENT

Vol. 10, No. 2, 2021, E-ISSN: 2226-6348 @ 2021 HRMARS

Reliability Analysis

Table 6: Reliability analysis of variables $(\mathrm{N}=115)$

\begin{tabular}{|l|c|c|}
\hline Variables & $\begin{array}{c}\text { Reliability Coefficient } \\
\text { (Cronbach alpha) }\end{array}$ & Item Number \\
\hline Teacher Performance (IV) & 0.607 & 4 \\
\hline Student Performance (IV) & 0.616 & 4 \\
\hline Administrative Performance (IV) & 0.607 & 7 \\
\hline The usage of EMIS (IV) & 0.614 & 5 \\
\hline Teaching-Learning Development (DV) & 0.630 & 5 \\
\hline
\end{tabular}

SPSS (version 25.0), a program created by IBM in Amund City, New York, was used to analyze all of the data. To determine the relevance of the data, a reliability test was performed (Nunnally, 1978; Nunnally \& Bernstein, 1994). With all items included, the reliability test values in table 6 indicate acceptable results. Cronbach's alpha, for instance, is 0.616 for student achievement. Furthermore, the reliability of all variables, including dependent and independent variables, is higher than the 0.6 cut-off value, indicating that reliability is accepted (Ursachi, 2013). As a consequence, the research instrument utilized in this study assesses several elements of the significance of using EMIS, such as teacher performance, student performance, and administrative performance, all of which may aid an educational institution in improving academic outcomes.

Table 7: Regression Analysis

\begin{tabular}{|l|c|c|c|l|}
\hline Variables & $\begin{array}{c}\text { Unstandardized } \\
\text { B }\end{array}$ & $\begin{array}{c}\text { Coefficient } \\
\text { Std. Error }\end{array}$ & $\begin{array}{c}\boldsymbol{P} \text { - } \\
\text { Value }\end{array}$ & \\
\hline (Constant) & 1.621 & 0.461 & .001 & \\
\hline Teacher Performance (IV) & 0.137 & 0.094 & .150 & $\mathrm{H}_{0} 1$ Rejected \\
\hline Student Performance (IV) & 0.182 & 0.095 & .058 & $\mathrm{H}_{0} 2$ Rejected \\
\hline Administrative Performance (IV) & 0.253 & 0.092 & .007 & $\mathrm{H}_{0} 4$ Accepted \\
\hline The usage of EMIS (IV) & 0.030 & 0.066 & .648 & $\mathrm{H}_{0} 3$ Rejected \\
\hline
\end{tabular}

The above table illustrates the significant impact of EMIS, student, teacher, and administrative performance on Teaching-Learning development for educational institutions. Each independent predictor gives an unstandardized and standardized beta coefficient that predicts each variable's positive or negative impact. In contrast, the $p$-value measures the significance of data at a 95\% confidence interval. Table 7 shows that $\mathrm{H} 1, \mathrm{H} 2$, and $\mathrm{H} 3$ have accepted and support the research result. At the same time, $\mathrm{H} 4$, which states that administrative performance has a significant impact on Teaching-Learning development,is proved to be rejected.

\section{Conclusions}

In every nation, EMIS may be improved to promote equitable and high-quality education and learning (Alshamsi, et al., 2020; Javed et al., 2020). The availability of ICT facilities is significant in educational institutions. This implies that monitoring and assessment must be improved (Hossain et al., 2018). Monitoring and assessment, technical support, benchmarking, and sharing of best practices may all contribute to a long-term EMIS that reflects the school's success. As a result, 
improving EMIS implementation in all educational institutions may result in higher-quality education and performance over time.

Furthermore, frequent monitoring and evaluation may aid the efficacy of EMIS in planning and execution by assessing the program's strengths and shortcomings, as well as if it helps to improving educational institutions' performance. The use of EMIS has a significant effect on the teaching-learning process. EMIS has a significant effect on all of the independent variables. Students' and instructors' performance on teaching-learning matters, while administrative performance has little bearing on teaching-learning growth. As a result, in light of the pandemic scenario, we should all work together to figure out the best methods to manage the education information system and its growth.

\section{References}

Al Qalhati, N., Karim, A. M., Al Mughairi, B., Al Hilali, K., \& Hossain, M. I. (2020). Study on Job Satisfaction among Teachers in Sultanate of Oman. International Journal of Academic Research in Business and Social Sciences. 10(10), 422-434.

Alshams, Y. A. A. B., Adaikalam, J., Karim, A. M., Hock, O. Y., \& Hossain, M. I. (2020). Application of Strategic Management Information System (SMIS) in the Ministry of Interior, UAE: Issues and Challenges. International Journal of Academic Research in Business and Social Sciences, 10(2), 346-361.

Enteria, Odinah \& Role, Mylene. (2018). Education Management and Information System (EMIS) for Public Elementary Schools. International Journal of Scientific Research and Management. 6. 10.18535/ijsrm/v6i6.el012.

Hossain, M. I., Limon, N., Amin, M. T., \& Asheq, A. S. (2018). Work Life Balance Trends: A Study on Malaysian GenerationY Bankers. IOSR Journal of Business and Management, 20 (9), 0109.

Javed, M., Hock, O. Y., \& Asif, M. K., Hossain, M. I. (2020). Assessing the Impact of Emotional Intelligence on Job Satisfaction among Private School Teachers of Hyderabad, India. International Journal of Psychosocial Rehabilitation. 24(4). 5035-5045

Unicef.org. (2021). Review of Education Management Information Systems (EMIS) that Track Individual Student Data. [online] Available at:

<https://www.unicef.org/eap/reports/review-education-management-informationsystems-emis-track-individual-student-data> [Accessed 18 June 2021]. 